\title{
Pembinaan Kepala Sekolah Dalam Upaya Meningkatkan Mutu Pendidikan
}

\author{
Aulia Nursyifa $^{\text {a,1 }}$, Nurzaman ${ }^{\text {b,2 }}$ \\ ${ }^{a}$ Fakultas Keguruan dan Ilmu Pendidikan, Universitas Pamulang* \\ ${ }^{\mathrm{b}}$ Fakultas Keguruan dan Ilmu Pendidikan, Universitas Pamulang \\ aulianursyifa@unpam.ac.id; dosen01907@unpam.ac.id \\ *korespondensi penulis
}

Diterima: 26 Februari 2019, Direvisi:12 Maret 2019, Disetujui:22 Maret 2019

\begin{abstract}
Abstrak
Faktor penentu peningkatan mutu pendidikan dilihat dari kualitas sumber daya manusia yang ada di sekolah. Kepala sekolah sebagai seorang pemimpin berperan penting dalam membina dan mengembangkan pendidik dan tenaga kependidikan di sekolah. Salah satu kendala dalam mengemban tugas sebagai kepala sekolah pada umumnya adalah kurangnya pemahaman kepala sekolah tentang tugas dan tanggung jawab yang harus dilakukan, sehingga mengakibatkan peran kepala sekolah belum maksimal dalam hal manajerial, pengembangan kewirausahaan, dan supervisi di sekolah. Pengabdian ini menggunakan metode pendidikan masyarakat dalam bentuk workshop yang bertujuan untuk meningkatkan pemahaman kepala sekolah tentang tugas dan tanggung jawabnya di sekolah. Hasil pengabdian masyarakat dapat dilihat dari antusias peserta dalam mengikuti serangkaian kegiatan workshop serta adanya peningkatan pemahaman kepala sekolah tentang tugas pokoknya sebagai kepala sekolah. Berdasarkan hasil pengabdian tersebut dapat disimpulkan bahwa peran kepala sekolah sangat berpengaruh pada kualitas pendidik dan tenaga kependidikan di sekolah. Kegiatan pengabdian ini diharapkan dapat dilaksanakan secara berkelanjutan sehingga dapat terjalin kerjasama Musyawarah Kerja Kepala Sekolah (MKKS) Tangerang Selatan.
\end{abstract}

Kata-kata kunci: Pembinaan, Kepala Sekolah, Mutu Pendidikan

\footnotetext{
Abstract

Improved quality of education viewed from quality human resources are there in the school. The principal plays an important role as a leader in fostering and developing the educational personnel and educators at the school. In the task given there are problems faced include a lack of understanding of the principal duties and responsibilities which should be exercised especially that has been set in the regulation, resulting in the role of principal yet to a maximum in terms of managerial, entrepreneurial development, and supervision at the school. This devotion uses the method of community education in the form of workshops aimed at improving the understanding of the principal about duties and responsibilities in the school. The results of the public service can be seen from enthusiastic participants in the workshop as well as a series of events following an increase in understanding of the principal of duty as head of the school. Based on the results of such devotion can be concluded that an increase in the professional head of the school is very influential on the quality of produce educators and educators at the school. This devotion activity expected to be undertaken on an ongoing basis so that it can intertwine cooperation Work Conference is the principal (MKKS) South Tangerang.

Keywords: Building, Principal, Education Quality
} 


\section{PENDAHULUAN}

Pendidikan yang berkualitas dapat dilihat dari kualitas sumber daya manusianya terutama kualitas para gurunya. Guru merupakan pendidik, dituntut meningkatkan kualitas profesionalisme dalam mengemban berbagai tugas pokok yang harus dijalani, misalnya mendidik peserta didik, mengajar berbagai hal kepada peserta didik, membimbing siswa dalam proses pembelajaran, menilai, melatih, mengarahkan peserta didik, sampai mengevaluasi peserta didik di berbagai jenjang pendidikan. Salah satu tugas guru yang perlu dipahami adalah tugas sebagai kepala sekolah.

Menurut Mulyasa (2007: 24) "kepala sekolah termasuk dalam komponen dalam pendidikan yang berperan dalam peningkatan kualitas pendidikan". Kepemimpinan tertinggi di sekolah yaitu kepala sekolah, oleh karena itu kepala sekolah selalu bertanggung jawab penuh akan penyelenggaraan pendidikan di sekolahnya, kemampuan kepala sekolah untuk melakukan manajerial di sekolah, kepala sekolah mendayagunakan berbagai fasilitas yang ada di sekolah, melakukan supervisi dan training bagi guru dan tenaga kependidikan di sekolahnya. Kepala sekolah dapat dikatakan sebagai jenjang karir tertinggi guru di dalam dunia pendidikan.

Penjabaran pengertian kepala sekolah diatur dalam Permendikbud No. 15 Tahun 2018 dalam pasal 1 ayat 2 tentang Pemenuhan Beban Kerja Guru, Kepala Sekolah, dan Pengawas Sekolah yang berbunyi sebagai berikut: "Kepala Sekolah adalah Guru yang bertugas memimpin dan mengelola Taman Kanak-Kanak (TK) atau bentuk lain yang sederajat, Sekolah Dasar (SD), Sekolah Menengah Pertama (SMP), Sekolah Menengah Atas/Sekolah Menengah Kejuruan (SMA/SMK)" (Kemendikbud, 2018).

Berdasarkan peraturan tersebut, kepala sekolah adalah guru yang diberikan tugas untuk menjadi pemimpin dalam berbagai jenjang pendidikan dasar sampai pendidikan menengah atas. Seorang guru yang memiliki kompetensi yang layak sebagai kepala sekolah dan telah memenuhi kualifikasi serta syarat tertentu maka guru tersebut dapat menjadi kepala sekolah.

Sebagai kepala sekolah yang memiliki tugas yang besar dalam memimpin sekolahnya, maka saat ini kepala sekolah tidak lagi memiliki kewajiban mengajar. Hal tersebut diatur melalui Permendikbud No. 15 Tahun 2018 dalam Pasal 9 Ayat 1 mengenai pemenuhan beban kerja guru, kepala 
sekolah, dan pengawas sekolah, yaitu "Kepala Sekolah melaksanakan tugas diantaranya: (1). melakukan manajerial, (2). melakukan pengembangan kewirausahaan, (3). melakukan supervisi kepada guru dan tenaga kependidikan" (Kemendikbud, 2018).

Berdasarkan peraturan tersebut kepala sekolah tidak memiliki kewajiban untuk mengajar tetapi lebih fokus pada tiga hal pokok dalam melakukan manajerial di lingkungan sekolahnya, mengembangkan kewirausahaan bagi warga sekolah, dan memberikan pengawasan dan penilaian kinerja guru dan tenaga kependidikan di sekolah.

Hal tersebut selaras dengan penelitian yang dilakukan oleh Karweti (2010) hasilnya adalah "kemampuan manajerial kepala sekolah sangat berpengaruh terhadap kinerja guru". Penelitian serupa dilakukan oleh Pratiwi (2013), “berdasarkan persepsi guru tentang kepala sekolah, kepemimpinan kepala sekolah memiliki dampak terhadap kinerja guru". Berdasarkan penelitian tersebut dapat disimpulkan bahwa kepala sangat berperan penting dalam peningkatan mutu pendidikan di sekolah, kemampuan manajerial dan gaya kepemimpinan yang dilakukan kepala sekolah dapat mempengaruhi kinerja guru sehingga kepala sekolah diharapkan dapat menjadi panutan bagi semua.
Selain itu kepala sekolah juga mengemban tugas lainnya yaitu sebagai guru, sebagai manajer, administrator, supervisor, pemimpin, inovator, motivator, dan sebagainya. Menurut Ramdani (2018:71) "kepala sekolah berperan penting dalam pembentukan karakter maupun performa sekolah, terutama dalam gaya kepemimpinan dan kreativitas warga sekolah".

Menurut Purwanto (2010) terdapat peranan seorang pemimpin yang sangat penting yaitu" sebagai pelaksana, perencana, perwakilan kelompoknya, seorang yang ahli dibidangnya, pengawas, penengah, pemberian pujian dan hukuman, pemegang tanggung jawab, pencipta, pemimpin lambang dari kelompoknya, pemimpin sebagai ayah, dan bertanggung jawab terhadap kesalahan kelompoknya”. Berdasarkan pendapat tersebut sangat banyak tugas yang dilakukan oleh pemimpin, begitupun yang harus dilakukan kepala sekolah karena keberhasilan sekolah dalam melaksanakan pendidikan ditangan peran kepala sekolahnya.

Dengan banyaknya tuntutan yang harus dilakukan dalam memimpin sekolah, oleh karena itu kepala sekolah haruslah orang yang benar-benar berkompetensi di bidangnya, dan dituntut untuk memiliki profesionalisme yang tinggi. Namun permasalahan yang terjadi yaitu terdapat 
kepala sekolah yang belum berkompeten di bidangnya, hal ini selaras dengan hasil pemetaan dari 31 provinsi di Indonesia yang menghasilkan bahwa rendahkan kompetensi dan supervisi para kepala sekolah, dibuktikan dengan hasil penelitian bahwa: "batas kelulusan kompetensi yang diterapkan bagi kepala sekolah yaitu minimal nilai 76 , namun kenyataannya yang didapatkan nilai 85 dilihat dari aspek kompetensi kepribadian, nilai 72 untuk supervisi, manajerial kewirausahaan rata-rata memiliki nilai 74, bahkan yang memprihatinkan nilai sosial rata-rata hanya 63”. (Kompas, 2012)

Berdasarkan Permendikbud No. 6 Tahun 2018 dalam Pasal 1 Ayat 4 tentang penugasan guru sebagai Kepala Sekolah, yang berisi: "Pendidikan serta pelatihan bagi bakal calon kepala sekolah bertujuan dalam rangka menyiapkan kompetensi untuk memantapkan wawasan, sikap, pengetahuan nilai, dan terampil dalam memimpin sekolah”. (Kemendikbud, 2003)

Peraturan tersebut menegaskan bahwa setiap guru yang diangkat menjadi kepala sekolah wajib melaksanakan berbagai pendidikan dan pelatihan kepala sekolah dengan memiliki berbagai kompetensi seperti wawasan, sikap, pengetahuan, nilai, dan terampil dalam memimpin sekolah.

Setelah adanya pendidikan dan pelatihan tersebut diharapkan kepala sekolah dapat menjadi pemimpin yang berkompetensi dibuktikan dengan adanya sertifikat kepala sekolah dari Kementerian Pendidikan dan Kebudayaan melalui Direktorat Jenderal Guru dan Tenaga Kependidikan. Bagi kepala sekolah yang belum memiliki sertifikat, maka wajib untuk mengikuti program pendidikan dan pelatihan tersebut, Jika tidak lulus maka diberhentikan dari jabatan sebagai kepala sekolah.

Dalam kondisi masa transisi pemberlakuan kedua Permendikbud tersebut, terdapat permasalahan yang diidentifikasikan yaitu kurangnya pemahaman kepala sekolah tentang Permendikbud No. 6 Tahun 2018 dan Peraturan Menteri Pendidikan dan Kebudayaan Nomor 15 Tahun 2018. Akibat minimnya pemahaman tentang peraturan tersebut sehingga mengakibatkan peran kepala sekolah belum maksimal dalam hal manajerial, pengembangan kewirausahaan, dan supervisi di sekolah. Kompetensi dan profesionalitas yang dimiliki kepala sekolah belum merata.

Dalam rangka memberikan solusi terhadap permasalahan mitra tersebut, maka dari itu tim dosen Pengabdian Kepada Masyarakat (PKM) Fakultas Keguruan dan Ilmu Pendidikan (FKIP) UNPAM bekerjasama dengan Musyawarah Kerja Kepala Sekolah (MKKS) di Tangerang Selatan menyelenggarakan workshop 
yang berjudul: "Pembinaan Kepala SMA Negeri dan Swasta di Tangerang Selatan"

Tujuan kegiatan pengabdian ini yaitu untuk meningkatkan pemahaman kepala sekolah tentang tugasnya dalam memimpin sekolah sebagaimana yang telah dijelaskan dalam Permendikbud No. 6 Tahun 2018 dan No. 15 Tahun 2018. Sehingga dengan adanya pengabdian ini dapat memberikan manfaat khususnya kepada kepala sekolah agar dapat meningkatkan mutu pendidikan.

Selain itu adanya kegiatan ini memberikan manfaat bagi para dosen dalam mengemban salah satu tugas Tridharma perguruan tinggi yaitu pengabdian kepada masyarakat sehingga menjadikan Fakultas Keguruan dan Ilmu Pendidikan Universitas Pamulang dapat berkontribusi secara nyata dalam dunia pendidikan di wilayah sekitar.

\section{METODE}

Pengabdian kepada masyarakat dilakukan menggunakan metode pendidikan masyarakat dalam bentuk workshop atau penyuluhan yang bertujuan untuk meningkatkan pemahaman kepala sekolah tentang tugas dan tanggung jawabnya yang terdapat dalam peraturan tersebut.
Pengabdian masyarakat ini menggunakan teknik observasi untuk melihat permasalahan awal yang dihadapi kepala sekolah yang ada di Tangerang Selatan sehingga dari observasi tersebut ditemukan permasalahan utama yang akan dijadikan sebagai landasan pelaksanaan pengabdian masyarakat ini. Sedangkan teknik wawancara untuk menganalisis permasalahan yang terjadi dengan berbagai narasumber dan untuk melihat peningkatan pemahaman peserta terkait dengan materi yang dipaparkan saat penyuluhan. Angket untuk melihat evaluasi pelaksanaan pengabdian masyarakat.

Kegiatan ini terlaksana berkat kerjasama tim dosen Fakultas Keguruan dan Ilmu Pendidikan Universitas Pamulang sebagai panitia sekaligus narasumber workshop yaitu: Dr. H. E. Nurzaman AM, MM., M.Si; Drs. H. Alinurdin., M.Pd; Aulia Nursyifa S.Pd M.Pd; Drs. Ahmad Nana Mahmur, M.Pd. Suanto S.Pd MH. Kegiatan workshop ini juga terlaksana atas kerjasama dengan kepala sekolah SMA Negeri dan Swasta di kota Tangerang Selatan yang bergabung dalam kelompok Musyawarah Kerja Kepala Sekolah (MKKS) kota Tangerang Selatan. 
Pengabdian kepada masyarakat ini diadakan di SMA Negeri 4 Tangerang Selatan pada tanggal 16 sampai dengan 18 Oktober 2018. Pemilihan tempat pengabdian didasari pada keberadaan SMA Negeri 4 Tangerang Selatan berada di wilayah Tangerang Selatan dekat dengan lokasi kampus. Hal ini menandakan bahwa Universitas Pamulang berkontribusi dengan dunia pendidikan di lingkungan Tangerang Selatan.

Subjek pengabdian masyarakat ini yaitu kepala sekolah SMA Negeri dan Swasta di wilayah Tangerang Selatan yang masuk dalam Musyawarah Kerja Kepala Sekolah (MKKS). Jumlah peserta yang mengikuti kegiatan pengabdian adalah 45 peserta.

\section{HASIL DAN PEMBAHASAN}

Pelaksanaan kegiatan pengabdian masyarakat berjalan sesuai dengan rencana mulai dari perencanaan sampai evaluasi kegiatan pengabdian masyarakat. Dalam tahap perencanaan tim dosen pengabdi melakukan observasi kepada kepala sekolah sehingga menemukan permasalahan pengabdian. Dilakukan wawancara dengan narasumber yaitu: "belum ada penyuluhan secara spesifik tentang tugas kepala sekolah, khususnya tentang sosialisasi Permendikbud No. 6 Tahun 2018 dan No. 15 Tahun 2018”. (Wawancara dengan narasumber, 2 September 2018). Hasil wawancara pendahuluan tersebut menjadi sebuah pedoman pengabdi untuk melakukan pengabdian masyarakat.

Dalam tahap perencanaan dilakukan pembentukan Tim dosen untuk melakukan pengabdian masyarakat, perencanaan waktu dan tempat pengabdian dan mengurusi izin pengabdian baik kepada Universitas Pamulang maupun perizinan ke tempat pengabdian di SMAN 4 Tangerang Selatan. Setelah itu, Tim pengabdian memberikan sosialisasi tentang workshop dan mengundang Kepala Sekolah SMA Negeri dan Swasta di Tangerang Selatan.

Pada tahap pelaksanaan kegiatan pengabdian berjalan lancar peserta workshop mengikuti kegiatan dari awal sampai akhir acara. Indikasi tingkat keberhasilan workshop dilihat dari jumlah peserta yang mengikuti kegiatan workshop berjumlah 45 peserta dari total 50 peserta undangan. Hal ini menandakan bahwa kepala sekolah membutuhkan kegiatan workshop ini.

\footnotetext{
Adapun rincian pelaksanaan pengabdian masyarakat dapat dijelaskan dalam gambar berikut ini:
} 


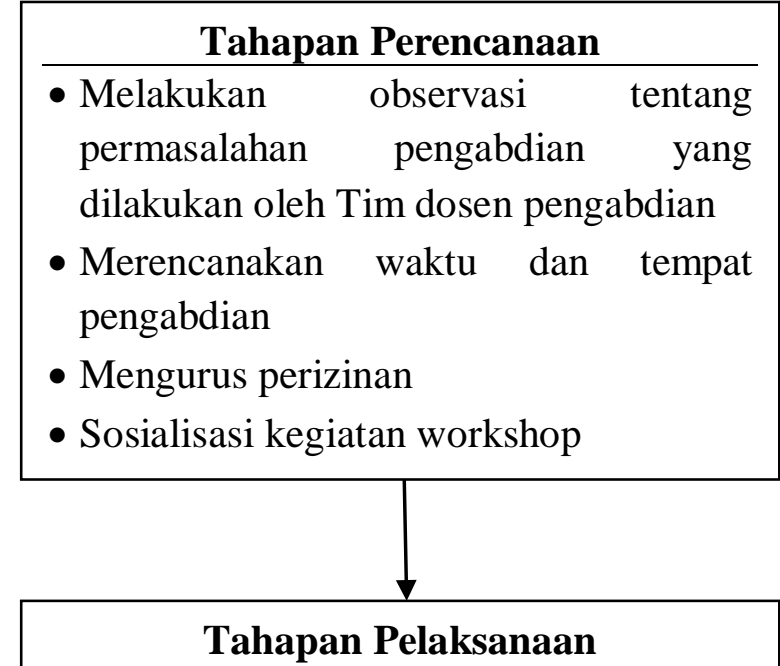

- Memberikan workshop tentang peran penting Kepala Sekolah dalam memahami tugas dan kewajibannya dalam memimpin sekolah

- Mensosialisasikan tugas kepala sekolah yang terdapat dalam Permendikbud No. 6 Tahun 2018 dan Permendikbud No. 15 Tahun 2018

- Diskusi tentang permasalahan yang dihadapi kepala sekolah saat ini terutama dalam pengembangan kompetensi dan profesionalitas kepala sekolah

\section{Tahapan Evaluasi}

- Mengevaluasi sejauh mana tingkat pemahaman kepala sekolah

- Adanya kegiatan tindaklanjut dengan menjalin kerjasama antara Musyawarah Kerja Kepala Sekolah (MKKS) Kota Tangerang Selatan dengan FKIP UNPAM
Penyampaian materi pertama disampaikan oleh narasumber Dr. H. E. Nurzaman AM, MM., M.Si tentang "Pembinaan Kepala SMA Negeri dan Swasta Terhadap Pendidik dan Tenaga Kependidikan".

Pemateri kedua yaitu Drs. $\mathrm{H}$. Alinurdin., M.Pd. tentang materi "Kepala Sekolah dalam Manajemen Pengimplementasian Kurikulum 2013”.

Pemateri ketiga yaitu Drs. Ahmad Nana Mahmur, M.Pd sebagai dosen sekaligus ketua MKKS Tangerang Selatan memberikan materi tentang "Peran MKKS dalam Meningkatkan Mutu Pendidikan”.

Dalam pelaksanaan workshop para narasumber juga memberikan sosialisasi tentang tugas kepala sekolah yang terdapat dalam Permendikbud No. 6 Tahun 2018 dan No. 15 Tahun 2018.

Temuan yang ada saat kegiatan workshop yang didasarkan hasil observasi yaitu sebelum kegiatan workshop sebesar $60 \%$ kepala sekolah belum mengetahui dan memahami tentang Permendikbud No. 6 Tahun 2018 dan Permendikbud No. 15 Tahun 2018.

\section{Gambar 1}

\section{Rincian Kegiatan Pengabdian}




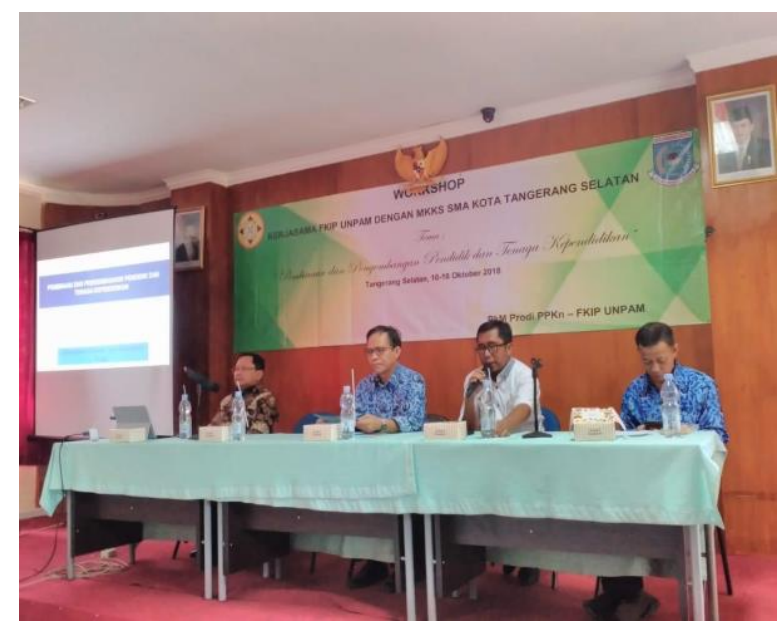

Gambar 2

Pelaksanaan Kegiatan Workshop

Setelah adanya workshop dilakukan wawancara kepada para peserta didapatkan sebesar $100 \%$ kepala sekolah tidak hanya mengetahui tentang Permendikbud No. 6 Tahun 2018 dan Permendikbud No. 15 Tahun 2018, namun juga memahami akan isi yang ada di dalam peraturan tersebut.

Dengan adanya peningkatan pemahaman tersebut diharapkan dengan mengetahui aturan yang ada maka dapat diimplementasikan di sekolahnya masingmasing dan kepala sekolah dapat memimpin sekolahnya dengan kompeten untuk membina para pendidik dan tenaga kependidikan yang profesional.

Dalam sesi diskusi para peserta sangat antusias berpartisipasi aktif dengan menyampaikan berbagai pertanyaan terkait dengan tugas dan tanggung jawab sebagai kepala sekolah. Kegiatan diskusi ini dipandu oleh Aulia Nursyifa S.Pd M.Pd dan Suanto S.Pd MH.

Berikut ini dokumentasi partisipasi aktif peserta dalam kegiatan pengabdian masyarakat.

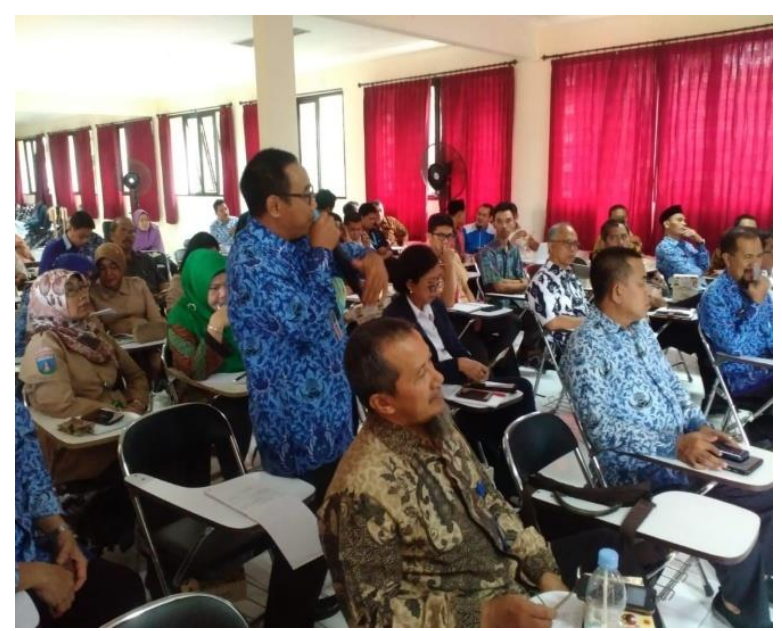

Gambar 3

Partisipasi Aktif Peserta

Dari berbagai pertanyaan yang ada menitikberatkan bahwa kepala sekolah harus meningkatkan kompetensi yang dimilikinya dan menjalankan tugas dengan profesionalitas yang berpedoman dengan aturan yang telah dipaparkan tersebut. Jika kepala sekolah profesional maka akan berimbas pada peningkatan profesionalitas para guru.

Penelitian yang dilakukan oleh Abubakar (2010: 116) disimpulkan bahwa "peran kepala sekolah dalam meningkatkan profesional dilakukan dengan berbagai cara: pelatihan, pembinaan, pengembangan karir, sertifikasi, memberi penghargaan, mengatur suasana kerja, melakukan kerjasama yang 
baik, dan pengembangan nilai-nilai spiritual di sekolah".

Solusi dari permasalahan yang diungkapkan kepala sekolah salah satunya dapat dilihat dengan mengadopsi dari pemikiran Ki Hajar Dewantara, maka seorang pemimpin dalam pendidikan harus menjalankan peranan yaitu dengan semboyan : ing ngarso sung tulodo, ing madyo mangun karso, ing tut wuri handayani.

Seorang kepala sekolah sebagai seorang pemimpin yang dapat menjadi teladan bagi yang dipimpinnya, tetapi juga harus member memotivasi dan memberikan dorongan moral dari belakang bagi orangorang yang dipimpinnya.

Penelitian yang dilakukan oleh Wenti (2013: 126) yaitu “Konsep Trilogi Ki Hajar Dewantara merupakan konsep kepemimpinan yang bersifat demokratis dengan prinsip keteladanan, partisipasi, kooperatif, dan memberikan kebebasan untuk mengembangkan sekolah".

Temuan lainnya yang dilakukan yaitu tidak semua kepala sekolah menjalankan tugasnya sesuai dengan undang-undang yaitu: tugas pokok dalam hal manajerial sekolah, mengembangkan kewirausahaan sekolah, melakukan supervisi kepada guru dan tenaga kependidikan.
Setelah adanya workshop ini diharapkan kepala sekolah dapat menjalankan tugas pokoknya tersebut sehingga dapat meningkatkan mutu sekolah sesuai dengan 8 Standar Pendidikan. Dalam implementasi kurikulum 2013 maka kepala sekolah harus berperan aktif memenuhi tuntutan kurikulum.

Penelitian yang dilakukan oleh Usman (2013:1) "strategi kepemimpinan yang mendukung kurikulum 2013 meliputi keteladanan kepala sekolah; pembelajaran dalam kegiatan eksplorasi, elaborasi, konfirmasi dalam kegiatan di dalam maupun di luar kelas; membangun kultur sekolah yang baik; dan menguatkan usaha-usaha professional".

Tahapan evaluasi yang didasari pada hasil angket dari peserta workshop sebagai bahan evaluasi kegiatan workshop dapat disimpulkan bahwa peserta workshop menilai para narasumber dalam kegiatan workshop ini sangat berkompeten dibidang pendidikan misalnya narasumber: Dr. H. E. Nurzaman AM, MM.,M.Si. selaku Sekretaris Direktorat Jenderal Guru di Kementerian Pendidikan, sehingga pemaparan yang diberikan narasumber sangat menarik untuk disimak dan dapat dipahami sehingga workshop ini dapat bermanfaat bagi peserta workshop. Berikut ini dokumentasi dari pemaparan narasumber dalam kegiatan pengabdian masyarakat. 
Tidak hanya narasumber yang sangat kompeten dan berkualitas, pengabdian masyarakat ini juga dinilai sangat baik dalam hal manajemen waktu kegiatan yang tepat waktu, pelayanan yang baik dari tim dosen pengabdi, fasilitas dan sarana seminar yang sangat baik.

Implikasi dari kegiatan pengabdian kepada masyarakat ini yaitu adanya jalinan kerjasama antara kedua belah pihak antara Fakultas Keguruan dan Ilmu Pendidikan (FKIP) Universitas Pamulan dengan Musyawarah Kerja Kepala Sekolah (MKKS) SMA Kota Tangerang Selatan. Bahkan setelah kegiatan pengabdian ini, tim dosen pengabdi akan selalu berusaha untuk mendampingi Musyawarah Kerja Kepala Sekolah (MKKS) jika ada permasalahan ataupun permintaan penyuluhan kembali di masa yang akan datang.

Kerjasama antara Musyawarah Kerja Kepala Sekolah (MKKS) dengan Universitas Pamulang dapat dilihat dari adanya kerjasama dalam program jangka panjang, hal ini dapat dilihat dengan adanya pengadaan lembaga sertifikasi bagi kepala sekolah yang akan diselenggarakan oleh universitas Pamulang. Sertifikasi kepala sekolah dapat menjadi solusi yang tepat dalam meningkatkan kompetensi kepala sekolah karena dalam undang-undang telah disebutkan kepala sekolah wajib bersertifikasi.

Keunggulan dari kegiatan workshop yaitu peserta bertambah informasi tentang Permendikbud No. 6 Tahun 2018 dan Permendikbud No. 15 Tahun 2018. Selain itu peserta workshop dapat berpikir secara ilmiah dan kritis tentang permasalahan dalam menjalankan tugas tugas sebagai kepala sekolah.

Adapun kekurangan dari workshop yaitu persiapan kegiatan workshop harus dipersiapkan lebih lama lagi sehingga kegiatan workshop dapat dipersiapkan dengan baik sehingga menjadi perbaikan bagi workshop selanjutnya.

\section{KESIMPULAN}

Pembinaan kepala SMA Negeri dan Swasta di Tangerang Selatan dapat berjalan dengan lancar dilihat dari tingkat ketercapaian kegiatan pengabdian masyarakat dari mulai perencanaan sampai akhir kegiatan dapat berjalan dengan baik. Permasalahan dalam pengabdian ini tentang kurangnya pemahaman kepala sekolah mengenai tugas dan tanggung jawab sangat sesuai untuk diterapkan metode pendidikan masyarakat dalam bentuk workshop atau penyuluhan.

Hasil pengabdian masyarakat dapat dilihat dari antusias peserta dalam mengikuti serangkaian kegiatan workshop, dan dapat dilihat dengan adanya peningkatan 
pemahaman kepala sekolah tentang tugas pokok sebagai kepala sekolah.

Kegiatan pengabdian ini bermanfaat tidak hanya bagi Universitas Pamulang tetapi juga bagi kepala sekolah yang tergabung dalam Musyawarah Kerja Kepala Sekolah (MKKS) Tangerang Selatan.

Kegiatan pengabdian ini diharapkan dapat dilaksanakan secara berkelanjutan sehingga dapat terjalin kerjasama Musyawarah Kerja Kepala Sekolah (MKKS) Tangerang Selatan.

\section{UCAPAN TERIMAKASIH}

Suksesnya acara workshop ini tidak terlepas dari peran dukungan baik dalam bentuk materil maupun moril semua pihak yang terlibat di dalamnya. Terimakasih kepada Yayasan Sasmita Jaya Universitas Pamulang, LPPM Universitas Pamulang, Dekan Fakultas Keguruan dan Ilmu Pendidikan Universitas Pamulang, Ketua Prodi Pendidikan Pendidikan Pancasila dan Kewarganegaraan, Para dosen pengabdi, Mahasiswa yang terlibat dalam pengabdian, Para Kepala Sekolah yang tergabung dalam Musyawarah Kerja Kepala Sekolah (MKKS) Tangerang Selatan, dan semua yang berkontribusi dalam pengabdian masyarakat ini.

\section{REFERENSI}

Abubakar, I. (2010). Peran Kepala Sekolah Sebagai Motivator Untuk Meningkatkan Profesionalisme Guru. Universitas Islam Negeri Sunan Kalijaga.

Karweti, E. (2010). Pengaruh Manajerial Kepala Sekolah dan Pengaruh Motivasi Kerja Terhadap Kinerja Guru. Jurnal Penelitian Pendidikan, 11(2), 77-89.

Kemendikbud. (2003). Permendikbud No.20

Tahun 2003. Diambil dari http://kelembagaan.ristekdikti.go.id

Kemendikbud. (2018). Permendikbud Nomor 15 Tahun 2018

Kompas. (2012). Kompetensi Kepala Sekolah Masih Rendah. Diambil 1 September 2018, dari https://edukasi.kompas.com

Mulyasa. (2007). Menjadi Kepala Sekolah Profesional. Bandung: Remaja Rosda karya.

Pratiwi, S. D. (2013). Pengaruh Motivasi Kerja, Kepemimpinan Kepala Sekolah, Kepuasan Kerja, Menurut Persepsi Guru dan Iklim Sekolah Terhadap Kinerja Guru. Jurnal Pendidikan Insan Mandiri, 1(1), 89-100.

Purwanto, N. (2010). Administrasi dan Supervisi Pendidikan. Bandung: 
Remaja Rosda Karya.

Ramdani, Z. (2018). Kolaborasi Antara Kepala Sekolah, Para Guru, dan Siswa.

In Prosiding 1st National Conference On Educational Assessment And Policy (hal. 71).

Usman, H. dan N. (2013). Strategi
Kepemimpinan Pembelajaran Dalam Menyongsong Implementasi Kurikulum 2013. Cakrawala Pendidikan, 1, 1-13. Wenti, S. (2013). Implementasi Trilogi Ki Hajar Dewantara Berkaitan Dengan Kepala Sekolah. Universitas Islam Negeri Sunan Kalijaga Yogyakarta. 